\title{
TURNOVER INTENTION ANALYSIS IN DIGITALIZATION ERA WITHIN COVID-19 PANDEMIC SITUATION
}

\author{
Lie Gunadi, Antonius Siahaan, Ardi Adji \\ Swiss German University, Tangerang, Indonesia
}

\section{Article Information}

Received: 31 August 2021

Accepted: 13 September 2021

Published: 15 October 2021

DOI: $10.33555 / \mathrm{embm} . v 9 i 1.196$.

\section{Corresponding Author:}

Lie Gunadi

Jakarta, Indonesia

Email: liegunadi3@gmail.com

ISSN $\quad 2338-8854$

eISSN 2620-9918

\begin{abstract}
The phenomenon of the digitalization era has an impact on high employee turnover. On the other hand, the COVID-19 pandemic impacted a lockdown in many countries and regions which in turn, in many businesses and employees being affected (reducing costs, reducing working hours, and even laying off work relations). Taking a sample of various organizations in Indonesia, this study analyzed the factors that cause employee turnover intention (dependent variable) such as employee satisfaction (moderating variable), also Remuneration and promotion, fringe benefit, working environment, and perceived external employment as independent variables. The research study was conducted based on 219 respondents who are in various industries. The results showed that working environment and fringe benefits have a positive impact to job satisfaction, job satisfaction has a negative impact to turnover intention and perceived alternate external employment has a positive impact to turnover intention inline with the predictions on the hypothesis. Meanwhile remuneration and perceived alternate external employment didn't have a significant impact on job satisfaction, as well as working environment, Remuneration and promotion, and fringe benefits to turnover intention.
\end{abstract}

Keyword: Fringe Benefit, Job External Employment, Perceived External, Remuneration and Promotion, Working Environment 


\section{Introduction}

Nowadays, digitalization is affecting nearly each sector of man activities. Digital Transformation has become one of the major trends that have been changing the business world. In fact, digitalization has arrived to abide as the 4.0 Industrial Revolution preserves evolving and effecting human's life in many manners (Gbadegeshin, 2019). The effect of the rise of digitalization increase in turnover among professionals and related job around the world. Meanwhile COVID-19, short of "Coronavirus disease 2019" pandemic impacted to decrease income and even job lost of the employees. This also has a big impact to the employee turnover. Usually the employee's exit begins with a desire or intention.

Turnover intention is the propensity or desire so that can be sincere or insincere going out of the job, and also moving out of the previous company into a new company based on its own choice (Silaban \& Syah, 2018). Employee turnover has always become one of the unseen enemy of business in many growing economics. Employee turnover can cause disturbance of operations, work team and unit performance. Both of these types of rotation come at a cost to the organization. Forbes said that for entry-level employees, mid-level employees, and highly skilledlevel employees, the associated cost comes to $30-50$ percent, 150 percent, and 400 percent of their annual salary respectively. It covers of replacement cost, training cost, and productivity cost. One of the worst impact of turnover is the exit of the employees usually will also result in some knowledge being out of the company.

The objective of this study is to analysis the turnover risk management by submitting an approach and constructing model which is related to the analysis of the causes of turnover intention in various organizations in the COVID-19 pandemic situation.

\section{Literature Review}

\subsection{Turnover Intention}

Voluntary turnover is the voluntary termination of a worker through their workplace. Turnover Intention is expressed as an employee's awareness or thought to stop working. Turnover intention is a worker's intentional and deliberate interest to quit the organization where they work (A. Rahman \& Syahrizal, 2019). Investigator tries to learn the main conclusive of turnover intention and build several managerial involvement for dealing to the obstacle of huge turnover rates (Tuzun, 2007). In the period of globalization, turnover is a steady obstacle in organizations and it is regular in each type and size of organization also at each organizational degree. Staff turnover is a serious obstacle notably in the place of human resources management (Chan Yin-Fah et al., 2010).

\subsection{Job Satisfaction}

Job satisfaction is a workers sensation of his/her peasure (Saeed et al., 2014). Employee satisfaction is very significant to the success of some business. A huge scale of worker satisfaction is nigh correlated to a down turnover scale. Therefore, to keep workers pleased, they ought to become a number one priority for every worker. Dissatisfaction with work may influence the worker's pleased which is very important to the success of all business. A huge scale of worker satisfaction is directly correlated to a lower turnover rate. Therefore, keeping employees pleased ought to be the first priority for every manager. Dissatisfaction with work may stem from stress or a mismatch between employees and jobs. Job satisfaction described by the reason of how people feel about their job also the difference factors of their job (Tuzun, 2007). There are several factors associated among pleasant work and turnover intention. Pleasant work affects employee attitudes on determining whether to stay or quit the organization. When the workers are unpleasant with their job, they will 
most likely quit the organization. If workers are sure that they are treated fairly and are rewarded, they will never quit from the organization (Aydogdu, 2011).

\subsection{Working Environment}

All the things which is exist around the workers and affect them in bringing out the duty assigned is called woek environment. When the work environment is cozy and sympathetic the workers are going to optimal work as workers find their pleased inside the work environment. The work environment is splited to two kinds :

1. Physical work environment that is composed by work environment which is directly correlated with employees likes central work, benches, tables, etc. and a middleman environment or common environment which can influence human situation likes lighting, noise, mechanical vibration, unpleasant odor, temperature, humidity, air circulation, color, etc.

2. Non-physical work environment that is includes all conditions correlating to job relations, good communication with superiors, peer coworkers, and with subordinates (Kurniawaty et al., 2019).

\subsection{Remuneration and Promotion}

Remuneration is the total benefits in money received by an employee. It not just only bases salary but also bonuses, commission payments, overtime pay, or other financial benefits that an employee receives from an employer. All businesses use the payment of wages, promotions, prize whether various kinds of prizes to drive high-level of workers accomplishment. Lack of promotions and casual job duties contribute greatly to employees' intentions to leave the company (Thomas, 2013). Promotion as far as a profession, an advancement alludes to the headway of an employee's position or position in a various leveled structure.

\subsection{Fringe Benefits}

Fringe benefits or additional benefits are indirect rewards which is given to a laborer or group of laborer as part of fellowship in an organization that impacts to employee accomplishment and conservation. The advantage gained is a significant piece of the human resources that come with the process because of the high cost and the financial commitments that are made over the long term. In according to adopt "job enrichment" program, some managers can hold workers also provide better career achievement chance. Apart from acceptance chance, the unstable choices and analysis of tariff criterion related to acceptance and prize systems also have a good impact in the intentions of organizational labors (Thomas, 2013).

\subsection{Perceived Alt External Employment}

Alternative employment refers to workers' confidence that they can find something comparable jobs at other organizations (Thatcher et al., 2002). Perceived external job vacancy, reputable too as apprehended easy action, is the insight of the provision of an alternative work. This insight is a problem that 3 cannot be controlled because it is very accurately correlated to the outside environment, respecting the existence of job vacancies and the number of thus express an important communication between job comfort and purposive turnover (Thomas, 2013). Alternative job opportunities are more perceived if the work market is rapid and solution of employment chance reduced when there is jobless. It ought to be noted, that Perceived alternate employment opportunities are not the same as real labour market situation. If the organization collapse to supply great progress chance, workers rigidly begin to look for alternative jobs and they will search based on believed chance outside the market (Rainayee, 2013). 


\subsection{Study Differences/Similarities}

The similarities of this research with the previous study is talking about employee satisfaction and employee turnover intention. Some study also mentions about working environment, Remuneration and Promotion, Fringe benefits, and perceived alternate external employment as independent variables. If we are looking of the differences, most of the previous study done in 'the normal situation', meanwhile this research is carried out during 'the COVID-19 pandemic situation'. In addition, there are some differences in the use of variables and demographics of the respondent.

\subsection{Research Model}

Refered to the literature review explanation above, the study model of this investigation identifies the independent variables/ factors, and then connected to the dependent variable as seen in construct examined as the figure below:

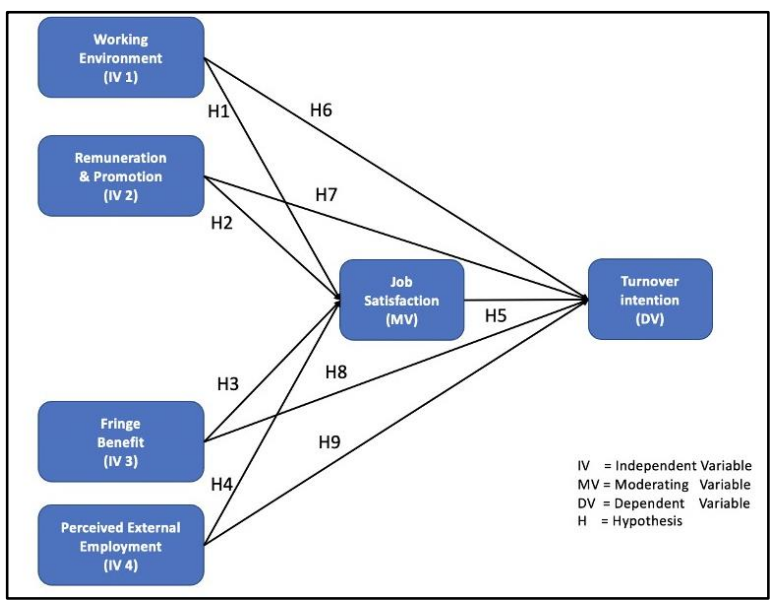

Figure 1. Research Model

Hypothesis is a proposed explanation for a phenomenon. For a hypothesis to be a scientific hypothesis, the scientific method requires that one can test it. Scientists generally base scientific hypotheses on previous observations that cannot satisfactorily be explained with the available scientific theories. The hypothesis of the study are:
H1: Working environment has a positive correlation towards job satisfaction

There is a good communication between working atmosphere and workers pleased job (Raziq \& Maulabakhsh, 2015).

\section{H2: Remuneration and Promotion has a positive correlation towards Job Satisfaction}

Remuneration is determined as one of the lock matters which is driving everyone to work. Nevertheles, its purpose for the workers and its impact on pleased work seems unclear. Remuneration generally seen as the most important variable used when clarifying all stages of enjoyable work. Some of the research indicate there is a relation between remuneration and job satisfaction but other research said there is nothing relation between remuneration and job satisfaction (Litwin, 2015).

\section{H3: Fringe benefits has a positive corre- lation towards job satisfaction}

Fringe benefits stand as a significant side of retribution but affirming their duty in deciding job satisfaction has been best mixed. The theory indicating this role is unclear. Fringe benefits indicate a hoped-for shape of retribution but but the result might be in cut earnings and lower job lower. Applying a merged contradiction of five NLSY waves, fringe benefits are build as important positive determinants of pleased work, even after setting for personal fixed impact and exemining in the endogeneity of fringe benefits (Raziq \& Maulabakhsh, 2015).

H4: Perceive external employment has a positive correlation toward job satisfaction

The significance of perceived alternate external employment (PAE) has gotten significance newly due to its important impact in organizational result (e.g., the intentions of turnover, the identification of organizational, the satisfaction of job, the commitment of organizational). The out- 
come showed that the satisfaction of the job in part interceded the correlation between PAE and turnover intentions, but PAE does not have a calming impact over the correlation between job satisfaction and turnover intentions of workers (Kamasak, 2011).

\section{H5: Job satisfaction has a negative corre- lation towards turnover intention}

Job satisfaction based on workers discovers their job satisfactory. The previous study proved that between the job satisfaction and turnover intention is exist negative relationship. If the job satisfaction is greater than the turnover intention, it will be smaller and vice versa. The higher difference between expected benefits and actual benefits the higher result in turnover intention will be (Saeed et al., 2014). There is an important impact of pleased work towards turnover intention and the impact is negative (Youcef et al., 2016).

\section{H6: Working environment has a negative correlation towards turnover inten- tion}

The work environment has a direct good impact on pleased work. This means that workers job satisfaction can be increased thru struggle to develop work environment both physically and non-physically in the shape of adequate supporting facilities. The work environment has a direct negative effect in turnover intention. This means that turnover intention is able to be reduced thru struggle to develop work environment both physically and non-physically (Kurniawaty et al., 2019).

\section{H7: Remuneration and promotion has a negative correlation towards turnover intention}

Compensation and advantages, exercising, accomplishment management, career establishment and employee relation management are important related to staff turnover intention (Long \& Perumal, 2014). Wage is probably one of the best ways to compensate the time and effort employees gave into the organization. Pay has a negative correlation to faculty intention stop (Joarder et al., 2015). Employees' compensation and career establishment impact a good and important effect on pleased work and negatively affect turnover intention, which is, if the compensation provided by the company can meet the need for employee desires, employee job satisfaction will increase and employee turnover will decrease rates (Rahman \& Syahrizal, 2019).

\section{H8: Fringe benefit has a negative towards turnover intention}

Fringe benefits or incidental advantages ordinarily incorporate health care coverage, bunch term life inclusion, instruction repayment, childcare and help repayment, cafétaria plans, representative limits, individual utilization of an organization claimed vehicle and other comparative advantages (Rahman, 2013). The vast majority of administrators in the private and public areas give a sort of benefits to add their pay rates. These are approached the-work advantages, ordinarily dependent on as incidental advantages, these are additionally seen as remuneration by a supervisor yet by and large excluded from a worker's available pay.

\section{H9: Perceive external employment has a positive correlation towards turnover intention}

Perceived salary competitiveness based on workers' view that their salary is comparable to colleagues in other organizations or industries. Compare payments with outside market can affect IT worker satisfaction. Perceived job alternatives give a strong direct influence to IT workers' turnover intention. When The external alternative work is good then the turnover intention increase and vise versa (Thatcher et al., 2002).

\section{Research Method}

\subsection{Research Design and Approach}

The Research philosophy in this research using philosophy of positivism. Philosophy of positivism believes that "actual" science gained thru observation (senses), include size, can be trusted. In positivism studies, the role of the investigator is limited to data 
collection and interpretation objectively interpreting the data.

Table 1. Research Methodology

\begin{tabular}{clll}
\hline No & Research Design & \multicolumn{1}{c}{ Research Approach } \\
\hline 1 & Research Philosophy & \multicolumn{1}{c}{ Positivism } \\
\hline 2 & Research Paradigm & \multicolumn{2}{c}{ Deductive } \\
\hline 3 & Research Strategy & \multicolumn{2}{c}{ Questionnaires } \\
\hline 4 & Research Methods & Choice & Quantitative \\
\cline { 3 - 4 } & & Time Horizon & Cross-sectional \\
\cline { 3 - 4 } & & Techniques \& & $\begin{array}{l}\text { Data collection, } \\
\text { sampling method } \\
\text { \&statistical analysis }\end{array}$ \\
& & & Procedures \\
\end{tabular}

Research paradigm reasoning is deductive. With conducting deductive research, the research always start with a theory (showed in study literature) then formulate a hypothesis, test the hypothesis with data collection, and analyst the result. The study conducts a quantitative method with crosssectional data in which the distribution of the questionnaire was devided in two stages. The main stage was to conduct a trial to determine whether further improvements to the measurement were needed, the second stage used actual data. These two trials used different or filtered questionnaires for different respondents compared to those who were accurate in the trial on the target population (variable observed without influencing the respondent). The respected constructs will be measured based on data collected using the sampling method from the survey and/or questionnaires and analysed using statistical tools. The data is gained via self-administered online questionnaire distributed to the randomly various industries worker. Online questionnaires will allow the respondents to complete the survey. The questionnaires will be distributed all at once towards the target respondents.

The International Labour Organization (ILO) (2020) indicates that approximately $7 \%$ of working hours are lost in the second half of 2020, quiting up to 200 million people unemployed. There may also be a significant increase in unemployment and a fall in wages. These numbers clearly show that COVID-19 is going to have a profound effect on people's careers and as a consequence a huge career shock for many of them (Akkermans et al., 2020). Employees who resign or leave the organization cause the company to lose important assets (knowledge, expertise, experience). A study conducted that Indonesia is the fourth highest turnover rate (15.8\%) (Ferdian et al., 2020). The research context of this study is an analysis of the turnover intention of various industries in Indonesia during the COVID19 pandemic.

This study uses two types of variables in research studies, Independent and Dependent variables. The research collects data from primary sources by distribute questionnaires that measures the six variables used, namely Job Satisfaction (independent variable), Remuneration and Promotion (independent variable), Work Environment (independent variable), Perceived Alternate Employer (independent variable), and Employee turnover intention as dependent variable. The dimensions and observed variables of each construct are outlined in the Tables below. The measurement of the respective constructs, which are the questionnaires obtained from previous studies.

Variable Working Environment has 13 statements (WE1 - WE13), Remuneration and Promotion 9 statements (RP1 - RP 9), Fringe Benefits has 7 statements (FB1 FB7), Perceived Alternate External Employment has 4 statements (AE1 - AE4), Job Satisfaction has 6 statement (JS1 - JS6), Turnover Intention has 5 statements (TI1 TI5). The operationalization of variables must be accurate with theory and basis by experiment to get accurate results. Researchers must first understand the types of variables that can help them identify impacts accurately and should drive future research. Entering each variable must apply first before being declared as the dependent or independent variable. Often a variable that is declared not clear hypothetical or has a different type of outcome must be analysed before it is operationalized. The variables most commonly used in research are the dependent variable and the independent 
variable. The variables that are used mostly in investigation are dependent and independent variables. The independent variable is annual income, company name and jobften named as the experimental or predictor variable. It is processed most of the time to store its affect on the dependent variable. The dependent variable is just a variable that hangs on the independent variable. The dependent variable depends on the decision by the independent change variable (Tariq, 2015).

Control variable in this study uses demographic data such as gender, age, education, position in the firm, tenure, company name, job name. These variables have been shown to affect the behaviour of each individual as they are the respondents of this research. Their positions in the firm is also recorded as control variable. From the operational variables, we make a questionnare by adding answer choices on a Likert scale of 4 (1-4), where 1 is SD = Strongly Disagree, 2 is $\mathrm{D}=$ Disagree, 3 is $\mathrm{A}=$ Agree and 4 is $\mathrm{SA}=$ Strongly Agree. (A likert scale tool is simple declaration that the participants are asked to submit a quantitative score on any objective statement, with level of agreement/disagreement most commonly used). Although scientifically it is still debated between odd and even Likert scales, this study chose a scale of 4 because it wanted to make it easier for respondents not to choose neutral values with simple scale values.

The questionnaires made by google forms and it distributed by whatsapp tools. The yields of respond rate from the respondents was $75 \%$. The final valid data are 219 respondents. The demographic result respondent are:

Table 2. Respondent by Gender

\begin{tabular}{ccrr}
\hline No & Gender & Frequency & Percentage \\
\hline 1 & Male & 164 & $74.89 \%$ \\
\hline 2 & Female & 55 & $25.11 \%$ \\
\hline & Total & 219 & $100 \%$ \\
\hline
\end{tabular}

Table 3. Respondent by Education

\begin{tabular}{llrr}
\hline No & \multicolumn{1}{c}{ Education } & Frequency & Percentage \\
\hline 1 & High School or equivalent & 19 & $8.68 \%$ \\
\hline 2 & Diploma (D1-D3) & 18 & $8.22 \%$ \\
\hline 3 & Bachelor (S1/D4) & 149 & $68.04 \%$ \\
\hline 4 & Magister (S2) & 31 & $14.16 \%$ \\
\hline 5 & Doctor (S3) & 2 & $0.91 \%$ \\
\hline & Total & 219 & $100 \%$ \\
\hline
\end{tabular}

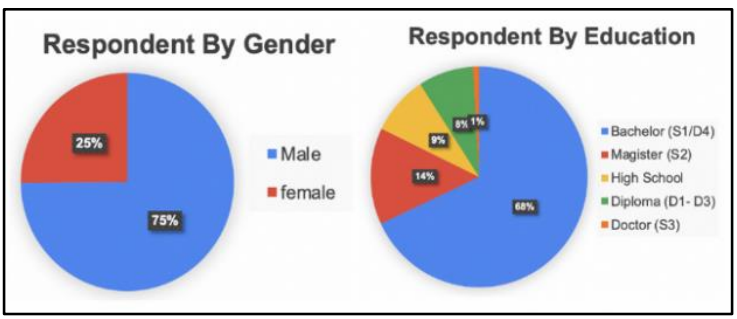

Figure 2. Demographic Respondents

Validity test is a trial of how well an instrument that is foster estimates the specific idea it is planned to gauge (Sekaran, 2016). The analysis starts from the validity test and reliability test, then continues with descriptive analysis to find out respondents' perceptions of the research variables and the last is verification analysis between variables. Decisions regarding the results of the validity test in this research questionnaire must compare the item correlation number with the total correlation obtained with the $r$ item number $>0.300$. Because the correlation number obtained in all item from the working environment, remuneration and promotion, fringe benefits, alternate external employment, job satisfaction and the turnover intention variable statement indicator is above 0.300 , the questions are decided to be significant and have good validity. Reliability is a trial of how reliably an estimating instrument estimates what ever idea it is estimating (Sekaran, 2016). Reliability test is used to see the stability or consistency of the measurement results. A measuring instrument is said to be reliable if it is used repeatedly on one object to produce the same results. The reliability technique used is the reliability of the consistency between the authors using the Cronbach alpha test. 
Based on the SEM Lisrel figure, two structural equations are obtained as follows:

$$
\begin{aligned}
& \text { 1. JS }=0.363 * \mathrm{WE}+0.112 * \mathrm{RP}+0.482 * \mathrm{FB} \\
& \quad+0.057 * \mathrm{AE} \\
& \text { Errorvar. }=0.229, \mathrm{R}^{2}=0.771
\end{aligned}
$$

2. $\mathrm{TI}=-0,098 * \mathrm{WE}+0.045 * \mathrm{RP}-0.012 * \mathrm{FB}$$$
+0.417 * \mathrm{AE}-0.456^{*} \mathrm{JS}
$$$$
\text { Errorvar. }=0.619, \mathrm{R}^{2}=0.381
$$

JS = Job satisfaction

TI = Turnover intention

$\mathrm{WE}=$ Working environment

$\mathrm{RP}=$ Remuneration and promotion

$\mathrm{FB}=$ Fringe benefits

$\mathrm{AE}=$ Perceived alt. ext employment

$\mathrm{R}^{2}=$ Squared multiple correlations or determination coefficient

From the first equation, it can be explained that the direction of the relationship between working environment, remuneration and promotion, fringe benefit and perceived external employment with job satisfaction is positive. The total effect of the first equation is $77.1 \%$. In the second equation, the direction of the relationship between working environment, fringe benefit and job satisfaction with turnover intention is negative, while the direction of the relationship between remuneration and promotion and perceived external employment with turnover intention is positive with a total effect of $38.1 \%$.

\section{Result and Discussion}

\section{H1: Working environment has a positive influence on job satisfaction}

HO: Working environment does not have a positive influence on satisfaction

The value of the regression standardizes coefficient (estimate) between the Working Environment variable and the Job Satisfaction variable is 0.363 (positive), which means that every increase in one unit of the Working Environment will increase Job Satisfaction by 0.363 units. Then has a t-count of 4.730 or greater than 1.96 then $\mathrm{HO}$ is rejected. This means that the Working Environment variable has a positive and significant effect on Job Satisfaction, so $\mathbf{H 1}$ is accepted. This result is in accordance with research conducted by Raziq \& Maulabakhs (2015) that there is a positive relationship between the working environment and job satisfaction in research in the banking, university and telecommunication sectors.

H2: Remuneration and promotion has a positive effect on job satisfaction

HO: Remuneration and promotion does not have a positive effect on job satisfaction

The regression standardizes coefficient (estimate) between the remuneration and promotion variable and the job satisfaction variable is 0.112 (positive) which means that every increase in one unit of remuneration and promotion will increase job satisfaction by 0.112 units. Then has a t-count of 1.427 or less than 1.96 then $\mathrm{H} 0$ is accepted. This means that the remuneration and promotion variable does not have a significant effect on job satisfaction, so $\mathbf{H 2}$ is rejected. There is literature about remuneration and promotions research to job satisfaction said that pay is not a motivator, but rather an assumed maintenance need. Thus, it is insignificant relation between remuneration and promotion to job satisfaction. There is no empirical evidence confirming that salary alone increases worker satisfaction or reduces production. The promotion has insignificant influence and partially significant to the job satisfaction. It is depend on the job situation and condition of the environment (Malik et al., 2012).

\section{H3: Fringe benefit has a positive influ- ence on job satisfaction \\ HO: Fringe benefit does not have a posi- tive effect on job satisfaction}

The value of the regression standardizes coefficient (estimate) between the fringe benefit variable and the job satisfaction variable is 0.482 (positive) which means that each increase of one fringe benefit unit will increase job satisfaction by 0.482 units. Then has a t-count of 5.262 or greater 
than 1.96 then $\mathrm{H} 0$ is rejected. This means that the fringe benefit variable has a positive and significant effect on job satisfaction, so $\mathbf{H 3}$ is accepted. This result is inline with the previous research about the positive impact of fringe benefits to job satisfaction (Chan Yin-Fah et al., 2010). Benjamin Artz (2010) in his journal said that fringe benefits pottentially resulting the higher job satisfaction of employee such as good absenteeism and low employee turnover. The advantage result from fringe benefits is significant of worker satisfaction that in the end will impacted to commitment of the employees such as productivity and cost finance in the long term (Thomas, 2013).

H4: Perceived external employment has a negative influence on job satisfaction

HO: Perceived external employment does not have a negative effect on job satsatisfaction

The value of the regression standardizes coefficient (estimate) between the perceived external employment variable and the job satisfaction variable is 0.057 (positive) which means that each increase of one unit of perceived external employment will increase job satisfaction by 0.057 units. Then has a t-count of 1.208 or less than 1.96 then $\mathrm{H} 0$ is accepted. This means that the perceived external employment variable does not have a negative and significant effect on job satisfaction, so $\mathbf{H 4}$ is rejected.

Explanation of the possibilities that occur in this study are:

a) The work of the respondent is generally quite good from various aspects (this is because the company where the respondent works generally has a good reputation such as United Tractors, Astra, SAP Indonesia, Microsoft Indonesia, Accenture and others). So, with a good reputation of the company even there are many opportunities come, the impact will not significant. b) Not many/rarely companies during the pandemic that can offer better jobs than the companies where they work now so that respondents feel they have to be more careful with alternative offers from outside parties. Or in other words, the opportunities outside are not better than the current job (it is better to stick with the existing job). This is correlated by the untested bonus question in questionnaire, which are generally answered because of the pandemic, respondents discouraged from looking for work outside.

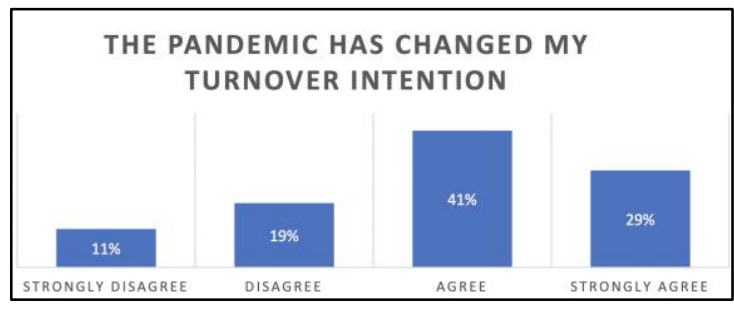

Figure 3. Pandemic Changed Respondents TI

Usually when workers see low external job alternatives, employee satisfaction will increase but when they see high external job alternatives, their job satisfaction will decrease. There is also a possibility because prestige does not need other alternative jobs. The outlook and expectations for alternative employment opportunities are also influenced by the employee market in common. (Ramlawati et al., 2021). When some workers see the alternative opportunities is saturated and it is very hard to seek alternative employment, they became happier with their existing job. But other study of perceived availability of job alternative said "A significant moderating effect was identified, since the survey results show interestingly, that employees who are satisfied in his/her job when high perceptions of available job alternative" (Rabbi et al., 2015).

\section{H5: Job satisfaction has a negative effect on turnover intention}

H0: Job satisfaction has no negative effect on turnover intention 
The value of the regression standardizes coefficient (estimate) between the job satisfaction variable and the turnover intention variable is -0.456 , which means that each increase in one unit of job satisfaction will decrease turnover intention by 0.456 units. Then has a t-count of -2.577 or the absolute value is greater than -1.96 then $\mathrm{H} 0$ is rejected. This means that the job satisfaction variable has a negative and significant effect on turnover intention, so $\mathbf{H 5}$ is accepted. This is in accordance with many previous studies. There is a negative corelation between the work satisfaction and employees' intention to leave. When the work satisfaction is bigger the employees' intention to leave will be lesser and vice versa. Therefore, the company should make their employees more pleased to reduce their intention to leave.

H6: Working environment has a negative influence on turnover intention

HO: Working environment does not have a negative effect on turnover intention

The value of the regression standardizes coefficient (estimate) between the working environment variable and the turnover intention variable is -0.098 which means that every increase of one working environment unit will decrease the turnover intention by 0.098 units. Then has a t-count of -0.840 or less than -1.96 then $\mathrm{H} 0$ is accepted. This means that the working environment variable does not have a negative and significant effect on turnover intention, so $\mathrm{H6}$ is rejected.

The reasons of the possibilities that occur in this study are:

a) In the good companies usually already have a good and specific working environment (respondent companies have a good reputation such as Astra, UT, SAP, Microsoft, Accenture and so on).

b) Pandemic situation also impacted to the respondent perception that very few good offerings working environment and insecure situation for new job. So, working environment doesn't have significant impact to turnover intention of the employees.

Meanwhile from literacy sometimes we can find the non-physical work environment could have a positive and insignificant effect on employees leave intention (Prawaty et al., 2020), especially in unnormal condition (COVID-19 pandemic situation).

H7: Remuneration and promotion has a negative effect on turnover intention HO: Remuneration and promotion has no negative effect on turnover intention

The regression standardizes coefficient (estimate) between the remuneration and promotion variable and the turnover intention variable is 0.045 (positive) which means that every increase in one unit of remuneration and promotion will increase turnover intention by 0.045 units. Then having a t-count of 0.408 or less than 1.96 then $\mathrm{H} 0$ is accepted. This means that the remuneration and promotion variable does not have a negative and significant effect on turnover intention, so $\mathbf{H 7}$ is rejected.

The reasons of the possibilities that occur in this study (based on focus group discussion) of several respondents which is part of the continuation of the questionnaries are:

a) Some higher level of employees with better competencies and educational event have a demanding beneficial than the lower one because they have the ability and a bigger chances to got new jobs, so sometimes employees with higher remuneration and promotion still have a big chance to leave (this against the formula that said The higher remuneration and promotion will make employee turnover intention decrease and vice versa).

b) On the other hand, the lower a person's income does not necessarily mean that the person will look for another job if the person concerned does not have 
sufficient competence so that there is a tendency for them to be more resigned, especially during a pandemic like this where it will be difficult to find work for those who do not have special skills or expertise qualified specific skills. For them it will be better to stay in the organization even with low pay and promotion.

From the literacy support 'Influence of salary satisfaction and organizational commitment towards turnover intention during pandemic COVID-19 situations' journal said that The presence of benefits and management commitment has insignificant impact (partial influence) toward leave intention because of pandemic situation (Putri \& Arquisola, 2021).

\section{H8: Fringe benefit has a negative effect on turnover intention \\ HO: Fringe benefit does not have a nega- tive effect on turnover intention}

The value of the regression standardizes coefficient (estimate) between the fringe benefit variable and the turnover intention variable is -0.012 which means that every increase of one fringe benefit unit will reduce turnover intention by 0.012 units. Then has a t-count of -0.076 or greater than -1.96 then $\mathrm{H} 0$ is accepted. This means that the fringe benefit variable does not have a negative and significant effect on turnover intention, so $\mathbf{H 8}$ is rejected.

In some cases when the business situation is not conducive people doesn't want to move further or to think there is an opportunity better outside his/her job. This is seen to be true in the answers to the questionnaire and FGD with respondents. Especially in pandemic situation where it is harder to find a job. This is proven that most of the respondent said that the

COVID-19 change their mind about turnover intention.

During this COVID-19 pandemic, the restrictions on community activities (lockdown) makes industrial activities difficult and there are many reductions in working hours and even layoffs everywhere, so many employees are grateful if they can still work (Since job security are lower in many industry). As literacy support said that internal company social responsibility activities such as workplace health benefits and its on employee wellbeing are less understood, especially during a pandemic situation where job security is relatively lower in many sectors of employment. Some initiative of other benefits that has no significant impact to the loyalty such as physical wellbeing towards worker loyalty and employee wellbeing towards worker loyalty. There is disassociation between wellbeing and loyalty which is typical behavior during crisis period (GorgenyiHegyes et al., 2021).

H9: Perceived external employment has a positive influence on turnover intention

H0: Perceived external employment does not have a positive effect on turnover intention

The value of the regression standardizes coefficient (estimate) between the perceived external employment variable and the turnover intention variable is 0.417 (positive) which means that each increase of one unit of perceived external employment will increase turnover intention by 0.417 units. Then having a t-count of 5.397 or greater than 1.96 then $\mathrm{H} 0$ is rejected. This means that the Perceived External Employment variable has a positive and significant influence on Turnover Intention, so $\mathbf{H 9}$ is accepted. This result is inline with the previous study that said there is positive impact from perceived alternate external employment to worker leaving intention (Treuren, 2013).

\section{Conclusion}

Through this research, the working environment and fringe benefits have a significant positive impact to job satisfaction. Likewise, the job satisfaction has a signifi- 
cant negative correlation to turnover intention and the perceived alternate external employment has a significant positive impact to the turnover intention. These significant relationship between the variables indicates that the initial hypothesis is proven.

Meanwhile, the correlation between remuneration and promotion and perceived alternate external employment on job satisfaction and turnovar intention is nonsignificantly positive. While the working environment and fringe benefits variables have a non-significant correlation to turnover intention. These non-significant relationships indicate that the initial hypothesis is not proven because of some reason that already explain in discussion.

Table 4. Hypothesis Result

\begin{tabular}{|c|c|c|c|c|c|c|c|c|}
\hline Hypothesis & \multicolumn{2}{|c|}{ Variable } & $\begin{array}{c}\text { Estima- } \\
\text { tion }\end{array}$ & SE & T-stat & t tabel & Result \\
\hline H1 & WE & $\rightarrow$ & JS & 0.363 & 0.077 & 4.730 & 1.96 & Significant \\
\hline H2 & RP & $\rightarrow$ & JS & 0.112 & 0.079 & 1.427 & 1.96 & Not Significant \\
\hline H3 & FB & $\rightarrow$ & JS & 0.482 & 0.092 & 5.262 & 1.96 & Significant \\
\hline H4 & AE & $\rightarrow$ & JS & 0.057 & 0.048 & 1.208 & 1.96 & Not Significant \\
\hline H5 & JS & $\rightarrow$ & TI & -0.456 & 0.178 & -2.577 & -1.96 & Significant \\
\hline H6 & WE & $\rightarrow$ & TI & -0.098 & 0.117 & -0.840 & -1.96 & Not Significant \\
\hline H7 & RP & $\rightarrow$ & TI & 0.045 & 0.109 & 0.408 & 1.96 & Not Significant \\
\hline H8 & FB & $\rightarrow$ & TI & -0.012 & 0.152 & -0.076 & -1.96 & Not Significant \\
\hline H9 & AE & $\rightarrow$ & TI & 0.417 & 0.077 & 5.397 & 1.96 & Significant \\
\hline
\end{tabular}

\section{Research Limitation}

The variety of hypothesis that are too many with many job and companies is the limitation of this study to conduct more detailed research. On the other hand, time is the biggest constraint to conduct further studies using the interview method or focus group discussions, especially to see whether the questions from the survey have been understood by the respondents. Moreover, some of the respondents did not want to be part of the research due to personal reasons. For respondents who are willing to answer, there is still the possibility of errors in answering considering that the answers are multiple choice which gives the respondent freedom to answer.

\section{Recommendations}

To see the accuracy of the survey on a more specific sample, further research is expected to be carried out on a specific job. In addition, considering that this research was conducted during the COVID-19 pandemic, which according to the answers of the majority of respondents influenced the answers given, especially on turnover intention, the research should also be carried out again in normal times.

Research study which show that there are some changes in turnover intention employees during the COVID-19 pandemic can be used as consideration for limited efficiency by taking into account the existing industrial and economic conditions. Therefore, further studies on the effectiveness of this efficiency must be carried out, so that it does not become counter-productive for the company.

Since this study is not specific on demographic data, it is a good idea if there is a study conduct in specific demographic such as specific job or gender or work experiences, position and so on. 


\section{References}

AK, B. (2018). Turnover intention influencing factors of employees: An empirical work review. Journal of Entrepreneurship \& Organization Management, 7(03), pp. 1-7. https://doi.org/10.4172/2169026x.100 0253

Akkermans, J., Richardson, J., Kraimer, M. L. (2020). The COVID-19 crisis as a career shock: Implications for careers and vocational behavior. Journal of Vocational Behavior, 119(May), pp. 1-5. https://doi.org/ 10.1016/j.jvb.2020.103434

Aydogdu, S. \& Asikgil, B. (2011). An empirical study of the relationship among job satisfaction, organizational commitment and turnover intention. International Review of Management and Marketing, 1(3), pp. 43-53. https://www.econjournals.com/index.p $\mathrm{hp} / \mathrm{irmm} /$ article/view/30/24

Chan Yin-Fah, B., Foon, Y. S., CheeLeong, L., \& Osman, S. (2010). An exploratory study on turnover intention among private sector employees. International Journal of Business and Management, 5(8), pp. 57-64. https://doi.org/10.5539/ijbm.v5n8p57

Ferdian, A., Luturlean, B. S., Suchita, N. B., \& Samsudin, A. (2020). Employees turnover intention in Indonesia: Do intrinsic motivation and affective commitment can overcome the problem?. TEST Engineering \& Management, 83(March-April), pp. 24456-24470.

Gbadegeshin, S. A. (2019). The effect of digitalization on the commercialization process of high-technology companies in the life sciences industry. Technology Innovation Management Review, 9(1), pp. 49-63. https://doi.org/10.22215/timreview/1 211
Gorgenyi-Hegyes, E., Nathan, R. J., \& Fekete-Farkas, M. (2021). Workplace health promotion, employee wellbeing and loyalty during COVID-19 pandemic large scale empirical evidence from Hungary. Economies, 9(2), 55 pp. 1-22. https://doi.org/10.3390/economies902 0055

Joarder, M. H. R., Subhan, M., Ghani, A. B. A., \& Islam, R. (2015). Pay, security, support and intention to quit relationship among academics in developing economy. Investment Management and Financial Innovations, 12(3), pp. 190199.

Kamasak, R. (2011). The influence of perceived external prestige on job satisfaction and turnover intentions. Journal of Business and Economics, 2(3), pp. 209-221. http://ssrn.com/ abstract $=1866670$

Kurniawaty, K., Ramly, M., \& Ramlawati. (2019). The effect of work environment, stress, and job satisfaction on employee turnover intention. Management Science Letters, 9(6), pp. 877886. https://doi.org/10.5267/j.ms1 .2019 .3 .001

Litwin, J. (2015). The relation between remuneration and job satisfaction: A case study of public administration employees in Pomerania Region in Poland. Social and Labour relations, 1(9), pp. 125-135.

Long, C. S., \& Perumal, P. (2014). Examining the impact of human resource management practices on employees' turnover intention. International Journal of Business and Society, 15(1), pp. 111-126.

Long, C. S., Thean, L. Y., Ismail, W. K. W., \& Jusoh, A. (2012). Leadership styles and employees' turnover intention: Exploratory study of academic staff in a Malaysian college. World Applied Sciences Journal, 19(4), pp. 575-581. https://doi.org/10.5829/idosi.wasj.201 2.19.04.155 
Malik, E. M., Danish, Q. R., \& Munir, Y. (2012). The impact of pay and promotion on job satisfaction: Evidence from higher education institutes of Pakistan. American Journal of Economics, 2(4), pp. 6-9. https://doi.org/10.5923/j.economics.20 120001.02

Prawaty, W. D., Dalimunthe, R. F., Gultom, P., \& Author, C. (2020). The effect of work stress and non-physical work environment on turnover intentions through job satisfaction as an intervening variable for employees of PT MNC Sky Vision Tbk. International Journal of Research and Review, 7(9), pp. 111-116. https://www.ijrrjournal.com/IJRR_Vol .7_Issue.9_Sep2020/IJRR0015.pdf

Putri, K., \& Arquisola, M. J. (2021). Influence of salary satisfaction and organizational commitment towards turnover intentions during pandemic COVID-19 situations. In Proceeding of International Conference Universitas Pekalongan, 1(1), pp. 91-98). Indonesia: Unikal.

Rabbi, F., Kimiya, F., \& Farrukh, M. (2015). The impact of job satisfaction, perceived availability of job alternative on turnover intention. Journal for Studies in Management and Planning, 01(11), pp. 319-328.

Rahman, A., \& Syahrizal, S. (2019). Effect of compensation and career development on turnover intention: Job satisfaction as a mediation variable. In Proceedings of the 2nd Padang International Conference on Education, Economics, Business and Accounting (PICEEBA-2 2018) (pp. 187-193). Atlantis Press. doi:https:// dx.doi.org/10.2991/piceeba2-

18.2019 .25
Rahman, M. M. (2013). A Comprehensive Relationship between Job Satisfaction and Turnover Intention of Private Commercial Bank Employees' in Bangladesh. International Journal of Science and Research, 2(6), 23197064. www.ijsr.net

Rainayee, R. (2013). Employee turnover intentions: Job stress or perceived alternative external opportunities. Business and Management, 5(1), pp. 48-60. http://www.ijibm.elitehall.com /IJIBM_Vol5No1_Feb2013.pdf\#page $=49$

Ramlawati, R., Trisnawati, E., Yasin, N. A., \& Kurniawaty, K. (2021). External alternatives, job stress on job satisfaction and employee turnover intention. Management Science Letters, 11, pp. 511-518. https:// doi.org/10.5267/j.msl.2020.9.016

Raziq, A., \& Maulabakhsh, R. (2015). Impact of Working Environment on Job Satisfaction. Procedia Economics and Finance, 23(October), pp. 717725. https://doi.org/10.1016/s22125671(15)00524-9

Saeed, I., Waseem, M., Sikander, S., \& Rizwan, M. (2014). The relationship of turnover intention with job satisfaction, job performance, leader member exchange, emotional intelligence and organizational commitment. International Journal of Learning and Development, 4(2). pp. 242-256. https://doi.org/10.5296/ijld.v4i2.6100

Sekaran, U., \& Bougie, R. (2017). Research methods for business a skill-building approach. Chichester: John Wiley.

Silaban, N., \& Syah, T. Y. R. (2018). The influence of compensation and organizational commitment on employees' turnover intention. IOSR Journal of Business and Management 20(3), pp. 1-6. $\quad$ https://doi.org/10.9790/487X2003010106 
Tariq, M. U. (2015). Operationalizing variables in theoretical frameworks: a comparative analysis. Durreesamin Journal, 1(1), pp. 1-11. https://sites .google.com/site/durreesamin/archive/ vol-1-no-1--march-2015

Thatcher, J. B., Stepina, L. P., \& Boyle, R. J. (2002). Turnover of information technology workers: Examining empirically the influence of attitudes, job characteristics, and external markets. Journal of Management Information Systems, 19(3), pp. 231261. https://doi.org/10.1080/07421222 .2002 .11045736

Thomas, J. (2013). Study on causes and effects of employee turnover in construction industry. International Journal of Science and Research, 14(5), pp. 3041-3044.

Treuren, G. (2013). The relationship between perceived job alternatives, employee attitudes and leaving intention. Anzam, pp. 1-18.

Tuzun, I. K. (2007). Antecedents of turnover intention toward a service provider. The Business Review Cambridge, 8(2), pp. 128-134.

Youcef, S., Ahmed, S. S., \& Ahmed, B. (2016). The impact of job satisfaction on turnover intention by the existence of organizational commitment, and intent to stay as intermediates variables using approach PLS in sample worker Department of Transport Saida. Management, 6(6), pp. 198-202. https://doi.org/10.5923/j.mm .20160606 .03 